\title{
Climate change and forest seed zones: Past trends, future prospects and challenges to ponder
}

\author{
by Dan McKenney ${ }^{1,2}$, John Pedlar ${ }^{1}$ and Greg O'Neill ${ }^{3}$
}

\begin{abstract}
Canada regenerates more than 400000 ha of forest land annually through planting and seeding operations. Much of the stock for this effort is selected to be climatically suited to the planting site-a match that is often facilitated through the development of seed zones. However, if climate change proceeds as predicted, stock that is well matched under current climate will be growing in sub-optimal conditions within the next 20 to 50 years-in some parts of the country, trees may already be growing outside their optimal climates. To provide a sense of the magnitude of these changes, we present past and predicted future climate trends for Ontario and British Columbia seed zones. For Ontario, over the period 1950 to 2005 , minimum temperature of the coldest month has already increased by up to $4.3^{\circ} \mathrm{C}$, growing season has lengthened by up to 6 days, and precipitation during the growing season has increased by up to $26 \%$. Changes were more pronounced across British Columbia’s Douglas-fir (Pseudotsuga menziesii [Mirb.] Franco) seed zones, with minimum temperature increasing by up to $8^{\circ} \mathrm{C}$, a growing season extension of up to 30 days, and growing season precipitation increases of up to $40 \%$. Projections for the end of the current century include: minimum temperature increase of $5^{\circ} \mathrm{C}$ to $10^{\circ} \mathrm{C}$, growing season extension of 31 to 60 days, and growing season precipitation increases of $3 \%$ to $42 \%$ across the seed zones in both provinces. These changes are certain to have extensive impacts on forest ecosystems. We briefly discuss 3 forest management adaptation strategies intended to mitigate the negative impacts of climate change in Canada.
\end{abstract}

Key words: climate change, seed zones, British Columbia, Ontario, Douglas-fir, seed transfer, assisted migration

\section{RÉSUMÉ}

Le Canada régénère annuellement plus de 400000 ha de forêt au moyen de travaux de plantation et d'ensemencement. La plus grande partie des stocks utilisés est sélectionnée afin dềtre climatiquement adaptée au site de plantation—un appariement souvent facilité par le développement de zones de provenance. Cependant, si les changements climatiques surviennent tels que prévus, les stocks qui sont adéquats sous les conditions climatiques actuelles se développeront en fonction de conditions moins qu'optimales au cours des prochaines 20 à 50 années-dans certaines régions du pays, des arbres pourraient déjà se développer dans des conditions hors des zones climatiques optimales. Afin d'illustrer lampleur de ces changements, nous présentons les tendances climatiques relevées dans le passé et prévues dans l’avenir pour les provenances retenues en Ontario et en Colombie-Britannique. En Ontario, pour la période de 1950 à 2005, la température minimale du mois le plus froid sest déjà accrue de $4,3^{\circ} \mathrm{C}$, la période de croissance sést allongée de 6 jours et les précipitations au cours de la période de croissance ont augmenté de $26 \%$. Les changements sont encore plus prononcés pour toutes les provenances de sapin Douglas (Pseudotsuga menziesii [Mirb.] Franco) en Colombie-Britannique, la température minimale ayant augmenté de $8^{\circ} \mathrm{C}$, la période de croissance gagnant jusquà 30 jours et les précipitations au cours de la période de croissance augmentant de près de $40 \%$. Les projections pour la fin du présent siècle sont : une augmentation de la température minimale de $5^{\circ} \mathrm{C}$ à $10^{\circ} \mathrm{C}$, un accroissement de la période de croissance de 31 à 60 jours et une augmentation des précipitations allant de $3 \%$ à $42 \%$ au cours de la période de croissance pour toutes les provenances des deux provinces. Ces changements provoqueront sans aucun doute des conséquences importantes au sein des écosystèmes forestiers. Nous abordons brièvement trois stratégies d’adaptation de laménagement forestier dans le but d’atténuer les effets négatifs des changements climatiques au Canada.

Mots clés : changements climatiques, provenances, Colombie Britannique, Ontario, sapin Douglas, transfert de semences, migration assistée

\footnotetext{
${ }^{1}$ Landscape Analysis and Applications Section, Canadian Forest Service, Great Lakes Forestry Centre. 1219 Queen Street E., Sault Ste. Marie, Ontario P6A 2E5.

${ }^{2}$ Author to whom all correspondence should be directed. E-mail: dmckenne@nrcan.gc.ca

${ }^{3}$ Kalamalka Forestry Centre, Research Branch, BC Ministry of Forests and Range, 3401 Reservoir Road, Vernon, British Columbia V1B 2C7; and College of Science and Management, University of Northern British Columbia, 3333 University Way, Prince George, British Columbia V2N 4 Z9 (adjunct).
} 


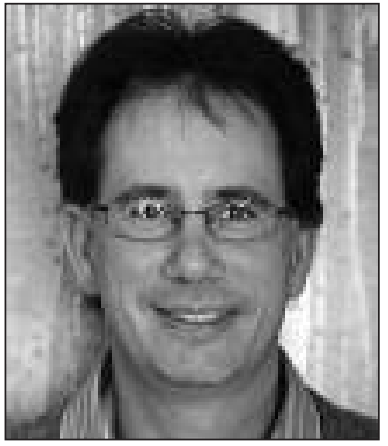

Dan McKenney

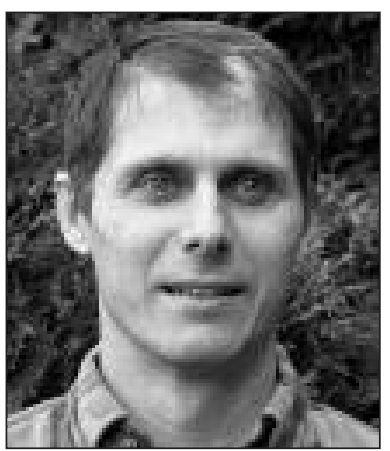

Greg O'Neill

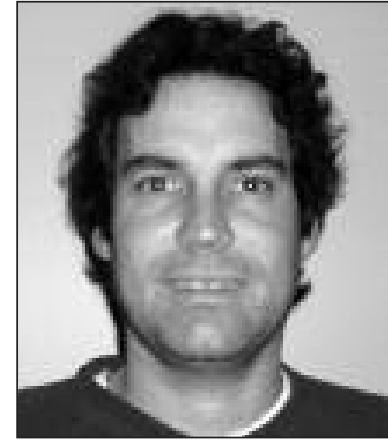

John Pedlar climate are expected to alter
Introduction and Motivation

The prospect of rapid climate change has far-reaching implications for the Canadian forest sector. Projected changes in forest productivity (Grant et al. 2007, Savva et al. 2007), shift tree species' distributions (Iverson and Prasad 2002, McKenney et al. 2007), and change the dynamics of natural disturbances such as forest fire (Flannigan and Van Wagner 1991, Stocks et al. 1998, Wotton et al. 2005), and insect outbreaks (Carroll et al. 2007, Gray 2008).

There is widespread interest in adapting forest management practices to lessen climate change impacts (Lemprière et al. 2008). However, identifying specific adaptation strategies at local scales is extremely challenging given the uncertainty surrounding key factors such as the ultimate effectiveness of internationally-driven climate change mitigation efforts, the accuracy of global and regional climate change models, the genetic adaptation and responses of plants to rapid climate change, and forecasting the effects of unforeseen disturbance agents such as fire, pests and the introduction of alien species (Botkin et al. 2007). Furthermore, the relatively slow rate of forest growth in relation to the projected trajectory of climate change over the coming century makes if difficult to respond rapidly as both challenges and new information arise (Jump and Penuelas 2005).

Below, we report the magnitude of recent, and projected, changes in climate for Ontario's seed zones (Fig. 1) and British Colombia's Douglas-fir seed zones (Fig. 2). We then very briefly present 3 forest management strategies that may help mitigate climate change impacts to Canada's forest plantations. By providing a seed management context our intent is to present the challenge of adaptation strategies in a more concrete setting and stimulate broader discussion around proposed strategies. If climate change proceeds as forecast, inter-jurisdictional cooperation on such mundane matters as seed management will be critical.

\section{Methods}

Historical climate data

The development of a national historical climate dataset has been described in detail elsewhere (McKenney et al. 2006a).
Climate station data (minimum temperature, maximum temperature, and precipitation) were obtained from Canadian and US sources for the period 1901 to 2003. Models were generated using the ANUSPLIN software package (Hutchinson 2004), which employs thin plate smoothing splines to develop, spatially continuous climate surfaces. From the primary climate variables numerous other bioclimatic indices were generated using the ANUCLIM (Houlder et al. 2000) and SEEDGROW (Mackey et al. 1996) software packages. Here we present results for just 3 of those climate variables that are thought to be important determinants of seedling survival and tree growth: growing season length (GSL), average minimum daily temperature of the coldest month (MINTCM), and precipitation during the growing season (PRECGS). Due to the sparse nature of the climate station network prior to 1950 (especially in the north), we present trends for the 1950 to 2005 period. Results for more variables and other parts of the country are available upon request. The models can also be viewed on an internet mapping system at http://cfs.nrcan.gc.ca/subsite/glfc-climate.

\section{Future climate data}

Future climate estimates were generated using outputs from 4 General Circulation Models (GCMs). These included the Canadian GCM (CGCM2; Boer et al. 2000), the UK-based Hadley GCM (HADCM3; Gordon et al. 2000), the Australian-based Commonwealth Scientific and Industrial Research Organisation GCM (CSIROMk2; Gordon and O'Farrell 1997) and the American-based National Centre for Atmospheric Research GCM (NCAR; Collins et al. 2006). Here we make use of the "A2" emissions scenario (Nakicenovic and Swart 2000, IPCC 2007). This scenario forecasts rapid human population growth, heavy deforestation, increased levels of air pollution, and $\mathrm{CO}_{2}$ emission rates that, by the end of the century, are about 3 times higher than current. Though this is considered by some as one of the more extreme scenarios developed by the International Panel on Climate Change (IPCC 2007), it describes a plausible future emissions path that can also be viewed as conservative given the rate of increase in greenhouse gas emissions in recent years (Raupach et al. 2007).

Raw GCM outputs were downscaled to provide greater spatial resolution by combining them with high-resolution surfaces of North American climatological normals for the 1971 to 2000 period (see McKenney et al. 2006b for details). Results are presented here for 3 future 30-year time periods ending on the years: 2040, 2070, and 2100 .

\section{Calculating trends}

For the historic trends, Canada-wide grids of the 3 climate variables of interest were overlaid onto maps of both the Ontario seed zones and BC Douglas-fir seed zones. Mean values were then calculated for each zone and year. Historical trends were based on a linear regression between year and each climate variable of interest. An autoregressive model was used to correct for serial correlation in the error term (SAS Institute Inc. 2003). The order of the autoregressive model used for each climate variable was determined using backward elimination starting with a 12th order autoregressive model. For future climate, means were obtained for each seed zone and time period. Change values were then calculated as the difference between current (i.e., 1971-2000) and future climate values. 

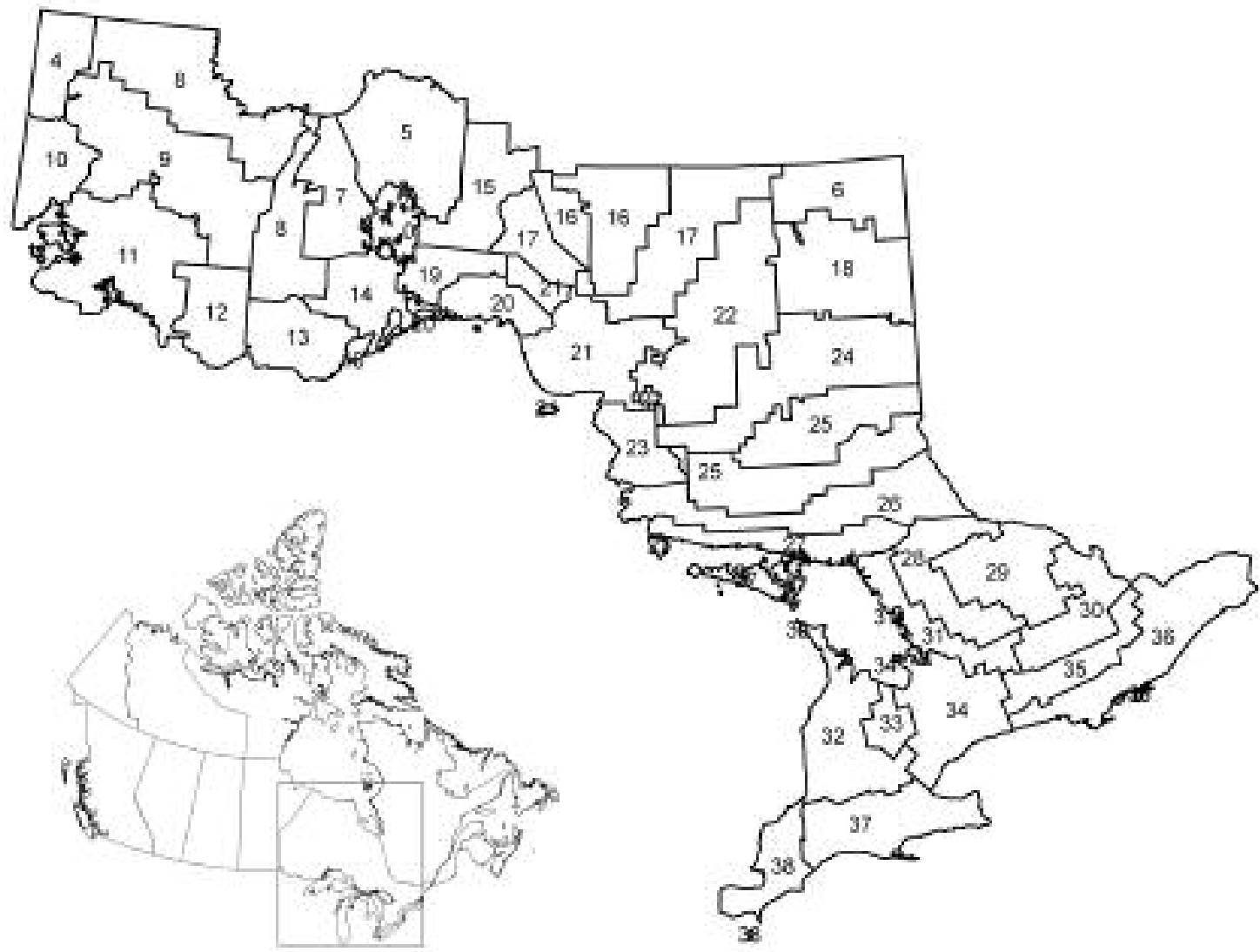

Fig. 1. Seed zones of Ontario.

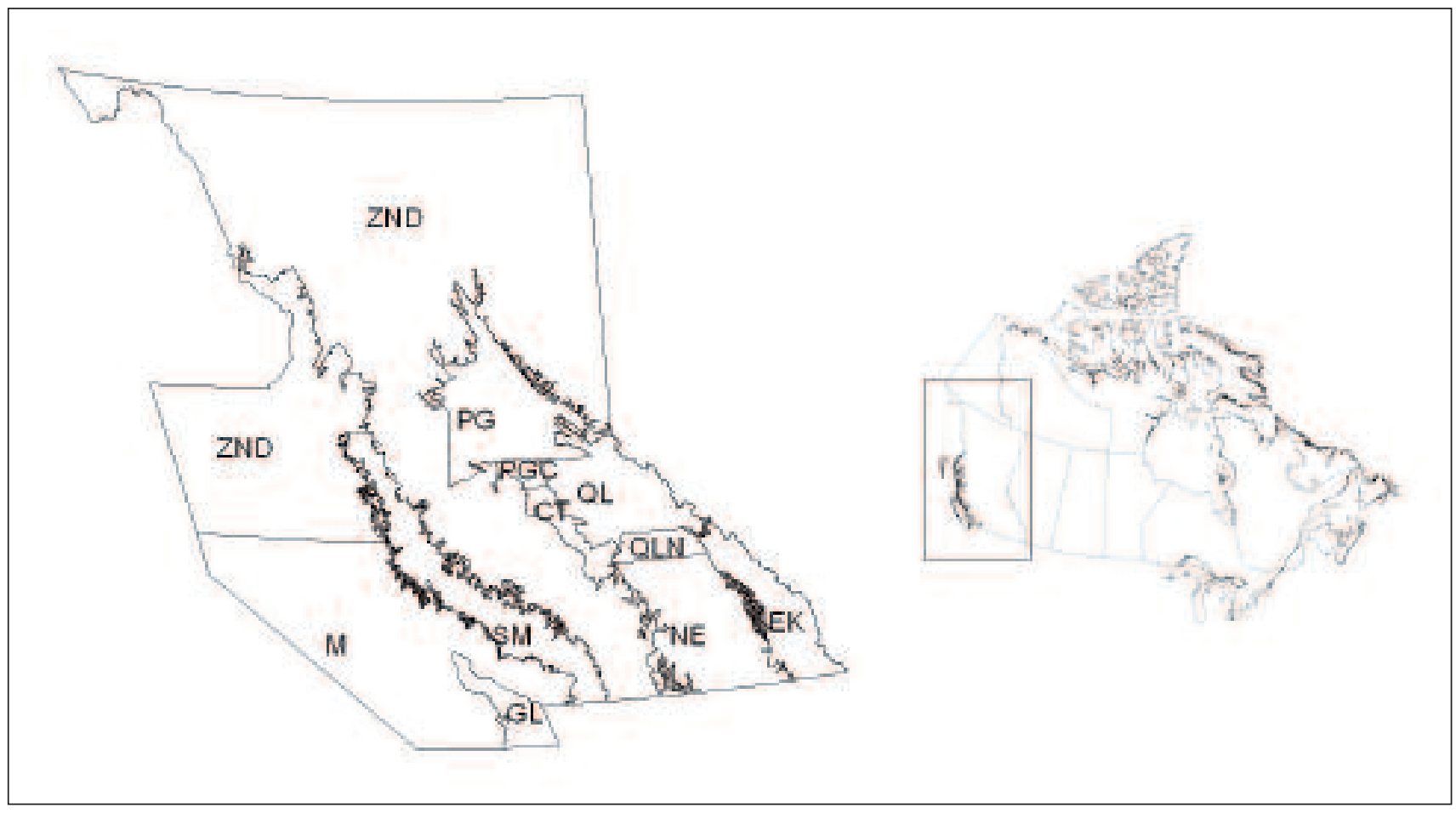

Fig. 2. Seed zones for Douglas-fir in British Columbia. See Table 1 for full seed zone names (ZND = zone not defined). 


\section{Results}

Over the period 1950 to 2005, changes in MINTCM varied from $-0.8^{\circ} \mathrm{C}$ to $4.3^{\circ} \mathrm{C}$ among Ontario's seed zones, with the largest changes occurring in seed zones from the northwest of the province (Fig. 3a). Future changes in MINTCM ranged from $1.5^{\circ} \mathrm{C}$ to $4.2^{\circ} \mathrm{C}$ for $2040 ; 4.5^{\circ} \mathrm{C}$ to $7.5^{\circ} \mathrm{C}$ for 2070 ; and $7.0^{\circ} \mathrm{C}$ to $10.3^{\circ} \mathrm{C}$ for 2100 (Figs. 3b-d). The spatial pattern of the predicted changes is relatively consistent across future time periods, with the greatest changes occurring in the eastern half of the province (Fig. 3b-d). Changes across the BC seed zones for Douglas-fir are somewhat more pronounced, with increases of $2.5^{\circ} \mathrm{C}$ to $7.5^{\circ} \mathrm{C}$ between 1950 and 2003 ; $1.6^{\circ} \mathrm{C}$ to $5.6^{\circ} \mathrm{C}$ for $2040 ; 3.2^{\circ} \mathrm{C}$ to $7.5^{\circ} \mathrm{C}$ for 2070 ; and $5.1^{\circ} \mathrm{C}$ to $9.7^{\circ} \mathrm{C}$ for 2100 (Fig. 4a-d). Temperature increases were most pronounced in seed zones located in the northeastern region of the province.

Recent changes in GSL followed a different spatial pattern than that of MINTCM, with increases of 6 or more days in northwestern (seed zones 5 and 7), central (seed zone 24), and southwestern (seed zones 37 and 38) regions of Ontario (Table 1). Substantial increases in GSL are predicted for each of the future time periods; by the end of the century some seed zones in southern Ontario may experience growing seasons that are extended by nearly 50 days (Table 1 ). Recent changes in $\mathrm{BC}$ have been more pronounced, with growing season extensions of 10 to 30 days across the Douglas-fir seed zones (Table 2). By the end of this century, growing seasons across the BC seed zones are projected to be extended by 40 to 60 days (Table 2).

Though driven by changes in temperature, the growing season trends differ from those of the temperature variables because growing season is calculated by accumulating the number of days that fall between a base temperature (i.e., $5^{\circ} \mathrm{C}$ ) for initiating growth in the spring and a minimum temperature for stopping growth in the fall (i.e., $-2^{\circ} \mathrm{C}$ ). Thus, temperature increases that occur in other seasons, or below the growing season thresholds, do not affect increases in growing season length.

Historical increases in PRECGS were greatest in the southern and northwestern regions of Ontario, while little or no change has been experienced in north-central areas (Table 1). PRECGS is projected to increase over the course of this century, particularly in the central part of the province, with increases of $20 \%$ to $30 \%$ by 2100 (Table 1 ). Historical increases in PRECGS varied from $10 \%$ to $30 \%$ across the British Columbia seed zones (Table 2). Growing season precipitation was also projected to increase in each future time period, with the greatest increases in the southwestern and southeastern seed zones (Table 2) where PRECGS is projected to increase by $35 \%$ to $50 \%$.

\section{Discussion}

\section{Climate change and impacts}

Our analyses indicate that substantial changes in temperature and precipitation have already occurred over the last half century across many Ontario and BC seed zones, with much larger changes predicted for the remainder of the current century. The results presented here are for only a few of the many climate variables that affect plant survival and growth. Extreme weather events (e.g., heavy rainfall, extreme temperatures, and strong winds) have also shown patterns of change over the last century that are consistent with elevated green-

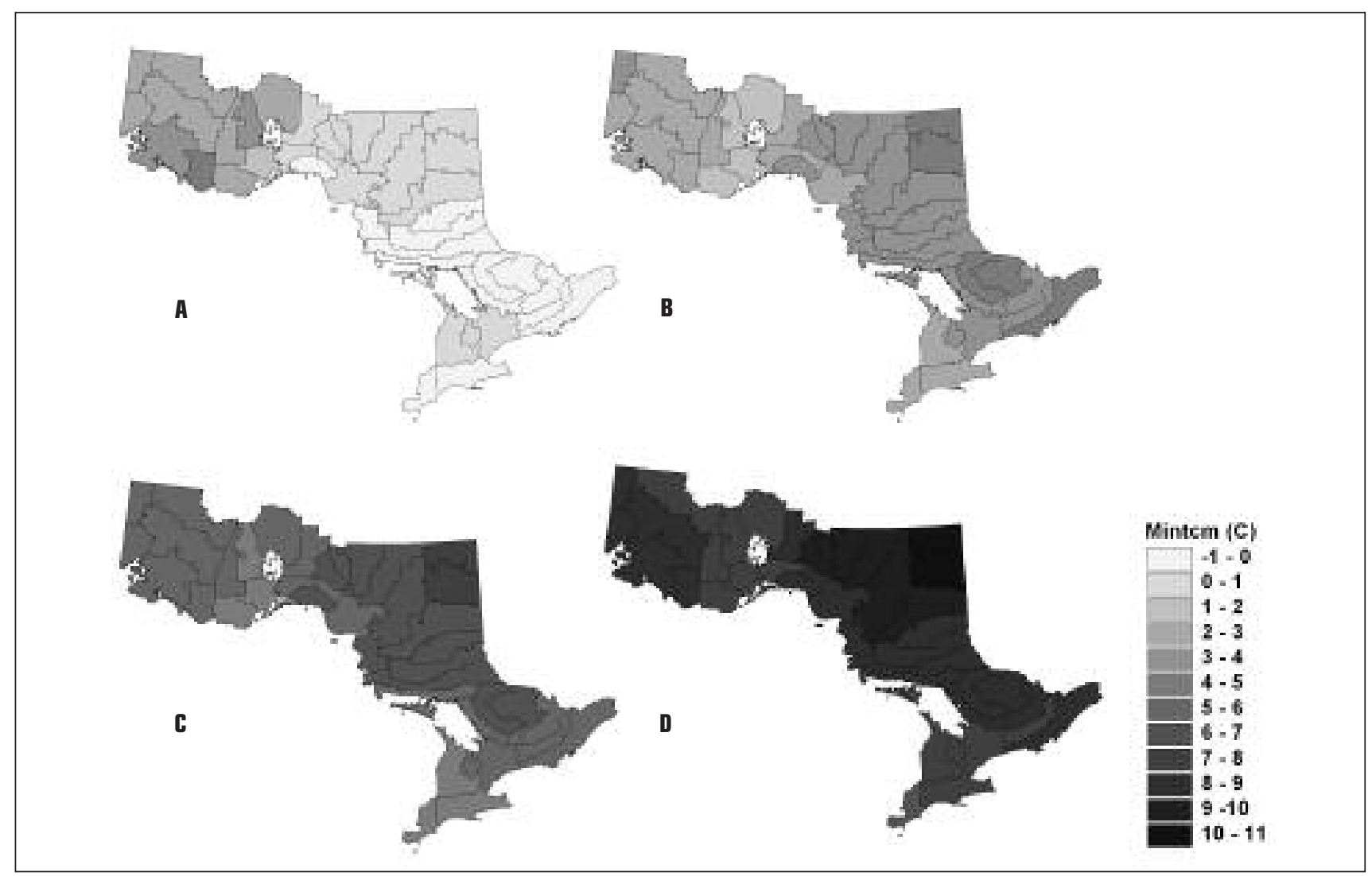

Fig. 3. Change in minimum temperature of the coldest month (degrees C) across Ontario seed zones for 4 time periods A) 1950-2003, B) 2011-2040, C) 2041-2070, and D) 2071-2100. Future changes are expressed relative to the 1970-2000 normal period. 


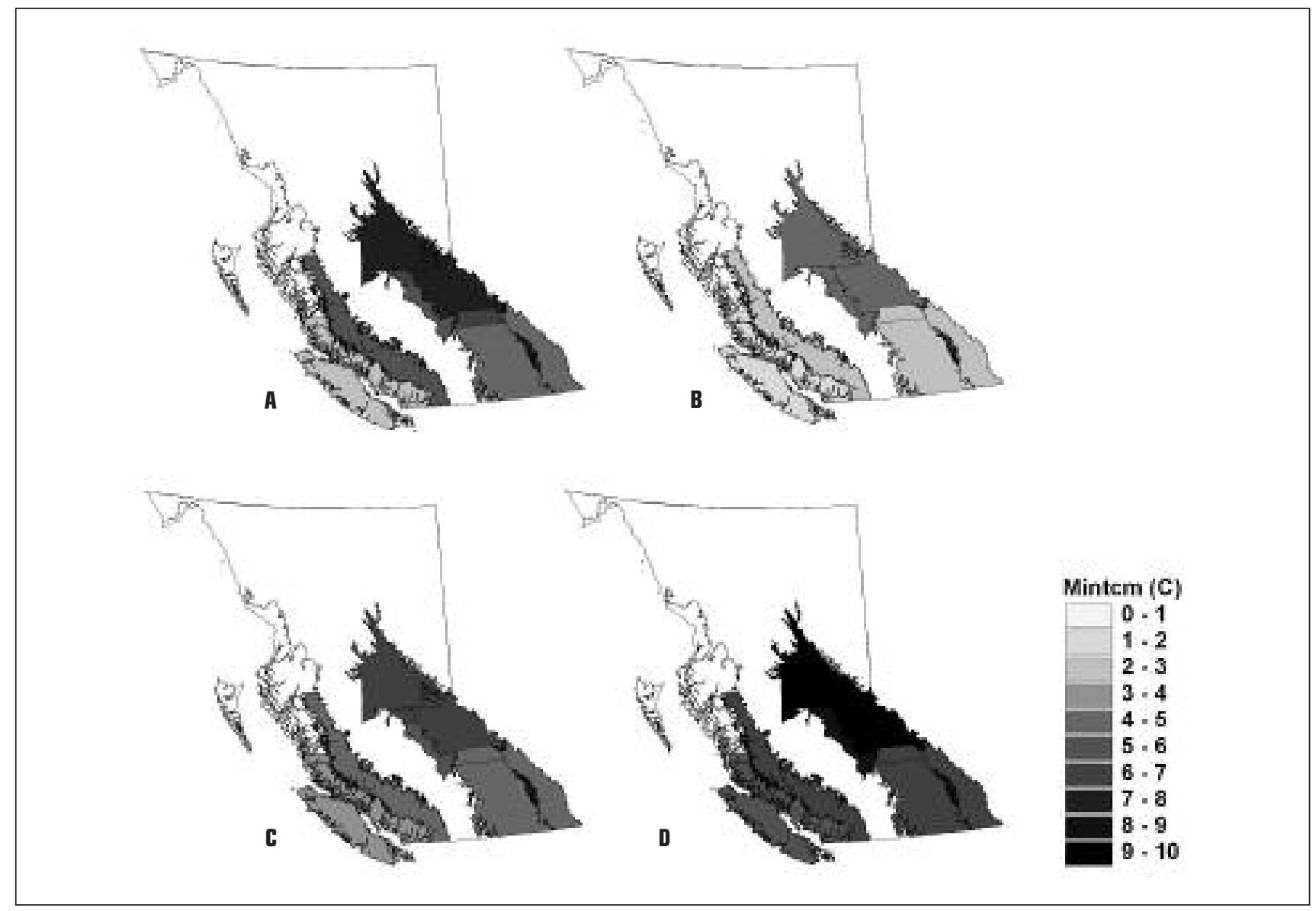

Fig. 4. Change in minimum temperature of the coldest month (degrees C) across BC seed zones for 4 time periods: A) 1950-2003, B) 2011-2040, C) 2041-2070, and D) 2071-2100. Future changes are expressed relative to the 1970-2000 normal period.

house gas emissions (Bonsal 2001, Zhang 2001, Vincent and Mekis 2006). Though not considered here, these and other weather anomalies such as freeze/thaw events may be particularly important to plant survival (e.g., Gu et al. 2008). We also note that the increases presented for PRECGS may be misleading in that the increased temperatures associated with climate change may also bring about higher levels of evaporation, which may nullify the predicted precipitation increases. In fact, estimates based on a climate-moisture index (Hogg 1997), which considers both precipitation and potential evapotranspiration, suggest that the water actually available to plants will decline for most forest regions in Canada by the end of this century (Lemprière et al. 2008).

The changes presented here are certain to have widereaching impacts on the growth, composition, and natural disturbance regimes of forest ecosystems-though the exact nature of these impacts is very difficult to predict. With respect to forest growth, responses are expected to vary by tree species and geographic location; trees located on the southern edge of their range would be expected to show growth declines, while increased growth is anticipated for those on the northern edge (Reich and Oleksyn 2008, Rehfeldt et al. 2001). This general pattern is overlaid by extreme weather events, such as the drought in the Canadian Prairies in 2000 to 2002 (Hogg et al. 2008) that nearly stopped the growth of Trembling Aspen on a regional scale, and by potential growth increases that may arise in some species in response to elevated atmospheric $\mathrm{CO}_{2}$ levels (Norby et al. 2005, Körner 2006).

Changes in forest composition can also be anticipated. McKenney et al. (2007) examined the effect of climate change on the geographic distribution of the climate habitat of 130 North American tree species. They reported an average northward shift in suitable climate of $700 \mathrm{~km}$ by the end of this century. Such rapid change in potential habitat will result in a major redistribution pressures for tree species across the continent. Given the northern situation and significant land base of both $\mathrm{BC}$ and Ontario, it is expected that suitable climate habitat will persist for most of the tree species that already occur in these provinces, while new climate habitat will be created for a number of southern species (McKenney et al. 2007). One major area of uncertainty is the degree to which species will track climate shifts. This will depend on natural tree migration rates, which are generally thought to be much slower than the predicted rate of climatic shift (i.e., $10-50 \mathrm{~km} /$ century; McLachlan and Clark 2004), and the extent to which humans assist with the migration process by establishing species in new locales (Hunter 2007, McLachlan et al. 2007).

Fire regimes are expected to intensify in response to climate change. Flannigan et al. (2005) predicted a $74 \%$ to $118 \%$ increase in annual area burned in Canada by the end of this century under recent emissions trends. Changes in insect distur- 
Table 1. Changes in growing season length and precipitation for past and future time periods across Ontario's seed zones. Future changes are expressed relative to the 1970 to 2000 normal period.

\begin{tabular}{|c|c|c|c|c|c|c|c|c|}
\hline \multirow[b]{2}{*}{ Seed zone } & \multicolumn{4}{|c|}{ Change in growing season length (days) } & \multicolumn{4}{|c|}{ Change in growing season precipitation (\%) } \\
\hline & $1950-2003$ & 2011-2040 & 2041-2070 & 2071-2100 & $1950-2003$ & 2011-2040 & 2041-2070 & $2071-2100$ \\
\hline 4 & 0.8 & 13.7 & 19.4 & 33.0 & 23.9 & 9.0 & 10.3 & 12.4 \\
\hline 5 & 6.0 & 7.6 & 17.0 & 31.8 & 2.8 & 8.5 & 11.8 & 16.4 \\
\hline 6 & 2.0 & 10.5 & 20.4 & 39.2 & 0.6 & 4.2 & 7.9 & 16.1 \\
\hline 7 & 6.7 & 9.8 & 18.2 & 31.2 & 5.4 & 6.2 & 8.3 & 11.4 \\
\hline 8 & 4.6 & 12.1 & 18.7 & 32.4 & 10.6 & 8.4 & 9.7 & 12.7 \\
\hline 9 & 3.8 & 13.3 & 18.8 & 32.8 & 20.2 & 5.5 & 6.1 & 8.6 \\
\hline 10 & -1.0 & 14.0 & 19.6 & 33.9 & 33.4 & 1.6 & 2.4 & 3.9 \\
\hline 11 & 1.7 & 13.4 & 19.0 & 33.8 & 25.3 & 3.2 & 4.0 & 6.0 \\
\hline 12 & 5.5 & 16.1 & 22.1 & 36.1 & 21.2 & 5.2 & 6.5 & 8.6 \\
\hline 13 & -0.1 & 14.1 & 22.2 & 36.6 & 7.3 & 8.4 & 11.0 & 14.2 \\
\hline 14 & 0.8 & 12.3 & 21.4 & 35.8 & 5.9 & 6.7 & 10.1 & 14.5 \\
\hline 15 & 2.1 & 9.8 & 20.0 & 35.2 & 3.7 & 8.8 & 12.9 & 18.1 \\
\hline 16 & 3.0 & 8.5 & 19.3 & 34.9 & 0.5 & 1.2 & 6.0 & 11.9 \\
\hline 17 & 2.2 & 9.7 & 20.1 & 36.3 & 1.8 & 4.2 & 8.8 & 15.3 \\
\hline 18 & 3.7 & 11.8 & 22.1 & 39.3 & 1.5 & 12.6 & 16.5 & 23. \\
\hline 19 & -0.4 & 12.5 & 22.2 & 37.6 & 4.7 & 8.0 & 12.2 & 17.8 \\
\hline 20 & 0.4 & 15.4 & 24.7 & 39.7 & 3.8 & 8.9 & 13.6 & 18.6 \\
\hline 21 & 3.0 & 13.8 & 23.8 & 39.0 & 3.3 & 8.5 & 14.3 & 19.4 \\
\hline 22 & 3.7 & 12.3 & 22.4 & 38.5 & 2.9 & 10.3 & 15.2 & 21.3 \\
\hline 23 & 0.7 & 15.8 & 27.5 & 42.4 & 4.8 & 18.4 & 28.3 & 34.0 \\
\hline 24 & 6.3 & 13.3 & 23.2 & 39.1 & 2.9 & 12.5 & 17.2 & 22.5 \\
\hline 25 & 5.4 & 14.4 & 24.6 & 39.9 & 7.0 & 11.2 & 17.7 & 23.0 \\
\hline 26 & 2.5 & 16.4 & 25.8 & 40.4 & 9.1 & 11.7 & 18.9 & 23.5 \\
\hline 27 & 1.2 & 15.8 & 24.4 & 39.3 & 16.8 & 8.1 & 15.0 & 19.9 \\
\hline 28 & 1.3 & 17.3 & 26.0 & 41.3 & 12.7 & 10.3 & 17.9 & 22.3 \\
\hline 29 & 2.9 & 15.5 & 25.7 & 42.4 & 14.0 & 9.7 & 18.2 & 22.7 \\
\hline 30 & -3.6 & 17.1 & 26.4 & 42.9 & 19.8 & 3.9 & 12.3 & 16.3 \\
\hline 31 & 0.1 & 17.2 & 25.3 & 40.8 & 12.4 & 6.7 & 14.4 & 19.0 \\
\hline 32 & 5.4 & 16.3 & 26.2 & 45.7 & 22.8 & 2.6 & 11.1 & 17.6 \\
\hline 33 & 5.8 & 16.8 & 25.4 & 43.2 & 21.7 & 7.1 & 15.0 & 20.3 \\
\hline 34 & 4.7 & 16.2 & 24.8 & 42.6 & 18.2 & 3.9 & 11.7 & 16.4 \\
\hline 35 & -1.1 & 16.8 & 25.0 & 40.8 & 26.2 & 1.5 & 10.0 & 13.9 \\
\hline 36 & -2.9 & 15.3 & 23.2 & 38.5 & 22.5 & 4.0 & 13.3 & 16.4 \\
\hline 37 & 8.1 & 15.3 & 26.0 & 45.1 & 26.1 & 2.4 & 11.3 & 16.9 \\
\hline 38 & 10.3 & 16.9 & 29.0 & 46.6 & 25.8 & 2.7 & 10.2 & 14.8 \\
\hline
\end{tabular}

Table 2. Changes in growing season length and precipitation for past and future time periods across British Columbia's seed zones. Future changes are expressed relative to the 1970 to 2000 normal period.

\begin{tabular}{|c|c|c|c|c|c|c|c|c|c|}
\hline \multirow[b]{2}{*}{ Seed zone } & \multirow[b]{2}{*}{$\begin{array}{l}\text { Zone } \\
\text { code }\end{array}$} & \multicolumn{4}{|c|}{ Change in growing season length (days) } & \multicolumn{4}{|c|}{ Change in growing season precipitation (\%) } \\
\hline & & $\begin{array}{c}1950- \\
2003\end{array}$ & $\begin{array}{c}2011- \\
2040\end{array}$ & $\begin{array}{c}2041- \\
2070\end{array}$ & $\begin{array}{c}2071- \\
2100\end{array}$ & $\begin{array}{c}1950- \\
2003\end{array}$ & $\begin{array}{c}2011- \\
2040\end{array}$ & $\begin{array}{c}2041- \\
2070\end{array}$ & $\begin{array}{c}2071- \\
2100\end{array}$ \\
\hline Cariboo Transition & $\mathrm{CT}$ & 9.2 & 13.6 & 32.1 & 54.8 & 25.5 & 3.2 & 11.0 & 18.4 \\
\hline East Kootenay & EK & 14.0 & 14.7 & 28.3 & 49.5 & 26.7 & 11.5 & 21.6 & 32.4 \\
\hline Georgia Lowlands & GL & 17.5 & 7.3 & 28.8 & 43.4 & 11.9 & -1.2 & 11.8 & 23.2 \\
\hline Maritime & M & 30.0 & 12.0 & 32.7 & 59.1 & 14.0 & 11.4 & 25.7 & 50.4 \\
\hline Nelson & $\mathrm{NE}$ & 14.3 & 15.7 & 29.0 & 51.9 & 28.7 & 6.8 & 15.8 & 27.9 \\
\hline Prince George & PG & 16.9 & 15.8 & 30.3 & 47.6 & 21.0 & 9.8 & 18.8 & 29.5 \\
\hline \multicolumn{2}{|c|}{ Prince George/ Cariboo Transition PGC } & 13.9 & 12.3 & 30.3 & 51.2 & 10.2 & 1.9 & 8.6 & 16.0 \\
\hline Quesnel Lakes & $\mathrm{QL}$ & 17.6 & 17.5 & 32.0 & 52.7 & 22.3 & 14.3 & 26.0 & 37.0 \\
\hline Quesnel Lakes/ Nelson & QLN & 18.1 & 16.3 & 29.7 & 51.1 & 32.9 & 12.1 & 22.8 & 35.1 \\
\hline Sub-maritime & $\mathrm{SM}$ & 24.7 & 12.4 & 28.6 & 52.0 & 33.8 & 9.9 & 20.5 & 44.6 \\
\hline
\end{tabular}


bance cycles are also difficult to predict under a changing climate; however, paleological data suggest that insect disturbance levels generally increase with temperature (Wilf and Labandeira 1999). The climate-induced outbreak of mountain pine beetle is evidence of the potential for unforeseen disturbance agents to arise under a changing climate (Carroll et al. 2007).

\section{Adaptation strategies}

Given the great uncertainty around the future of forests in Canada, many of those involved in forest management are wondering what can be done now to adapt to future change. This section discusses 3 forest management strategies intended to reduce the negative impacts of climate change on forest plantations.

\section{Adopt seed transfer guidelines}

Of the approximately one million ha of forest harvested each year in Canada, over 400000 ha are artificially regenerated through planting or seeding operations (Natural Resources Canada 2007). The remaining area essentially uses some form of natural regeneration. While the numbers vary annually, in 1999 about 2.5 billion seeds were collected for some 36 conifer and 29 broadleaf species (Morgenstern and Wang 2001). These numbers provide evidence of the importance and scope of seed management decisions across the country; almost half of the country's harvested landbase is regenerated artificially, which potentially involves moving genetic resources some distance from their point of origin. Clearly, managers are already making important decisions about the climatic tolerance and transferability of tree seed.

To ensure that plantations being established today will be adapted to future climates, it is first necessary to ensure that systems of seed transfer controls (also called seed procurement or seed transfer guidelines) are in place throughout Canada. Effective implementation of assisted migration of seedlots (see next section) can occur only if a system of seed transfer control is in place. Further, incorporation of assisted migration will be most prudent and effective in those seed transfer systems that are based on climate. We estimate that approximately only half of Canadian jurisdictions currently employ some form of seed transfer control.

Seed selection in Ontario is based on fixed seed zones (Joyce and White 2003), which are relatively homogeneous areas with respect to key climate variables (e.g., growing season length). In fixed zone systems, seed must remain within its zone of origin. Zones are often made "operational" by drawing boundaries to coincide with nearby geographic or administrative boundaries. British Columbia also has a long history of seed transfer development (Ying and Yanchuk 2006) that has produced separate seed zone maps for improved populations of major forest species. Several approaches have been used or proposed for delineating fixed seed zones, including regression techniques (Campbell 1979), cluster analysis (O'Neill and Aitken 2004), redundancy analysis (Hamann et al. 2000), differential systematic coefficient analysis (Parker 2000), and maximal covering location analysis (Crowe and Parker 2005). Varying degrees of attention and information inform the maximum climatic or geographic zone width employed in fixed zones systems (see Morgenstern [1996] for an excellent discussion of these issues including the concepts of seed zones and seed transfer).
An alternative seed transfer system is the floating or focal point seed zone approach (Rehfeldt 1983, Parker 1992, Parker and van Niejenhuis 1996), which provides for greater deployability than the fixed zone approach, but requires delineating a unique deployment zone around every seed source, or a unique seed procurement zone around every plantation. The size of the procurement zone around each plantation or the deployment zone around each seed source is defined by a maximum climatic or geographic transfer distance. Statistical approaches to calculate these distances seek to maximize the productivity of the plantation on the basis of transfer functions that use provenance test data to relate provenance productivity to the climatic or geographic distance each provenance is transferred (Raymond and Lindgren 1990). Alternatively, they seek to ensure that selected seed sources are adaptively similar to the natural populations in the area of the plantation (Lesser and Parker 2004).

There are still many locations and species in Canada for which seed transfer guidelines are lacking or for which provenance data are unavailable. In such cases, simple climate matching of sites and seeds could provide a vast improvement over uninformed seed selection. "SeedWhere" (McKenney et al. 1999) - an example of a simple tool developed for this purpose-operates as a focal point seed zone system that scores the climatic similarity between a site of interest and each cell across a region of interest in North America. An output map of the climate similarity index allows the user to view and choose the desired level of climate similarity for seed deployment or procurement and to select the climate variables to be used in the similarity index.

\section{Assisted migration of seed sources}

Climate change will impact forest health and productivity primarily because trees' annual growth cycle will become increasingly unsynchronized with the annual climate cycles in which trees evolved, resulting in cumulative maladaptation. In addition, increased pest concerns are anticipated because as the climate changes, trees may find themselves in climates suitable to pests to which they have not developed resistance. Consequently, planting seed sources adapted to future climates (i.e., assisted migration) is a pro-active strategy that addresses the fundamental issue of the uncoupling of plant adaptation to its environment (Rehfeldt et al. 2006, Millar et al. 2007) due to climate change.

Since tree growth happens over many years, there is a trade-off between choosing seed sources adapted to current conditions but perhaps less or even poorly adapted to expected future conditions and vice versa. The choice of which time period to target when making regeneration decisions will depend on the rotation length of the species. For short-rotation species (e.g., Populus spp.), targeting the climate projected for the 2011 to 2040 time period is likely reasonable, while a long-rotation species may have much of its life span or economic rotation tied to the climate of the midor even late-century time periods.

Methods have been developed to incorporate assisted migration into seed transfer systems (e.g., Parker et al. 2006) or to identify appropriate climate transfer distances to account for future climate change (Wang et al. 2006, Beaulieu and Rainville 2005). SeedWhere addresses assisted migration by replacing grids of current climate with grids of future climate 
of the user's choice to identify sites for seed procurement and deployment. The issue of assisted migration has been carried a step further in British Columbia, where seed transfer guidelines were recently modified to account not just for climate change in the near future, but also for climate change that has taken place over the last 100 years (O'Neill et al. 2008).

\section{Assisted migration of species}

To this point we have discussed assisted migration of seed sources as a key strategy to help maintain healthy and productive forests in the face of climate change. However, there is good evidence that species migration will also lag behind climate migration (Aitken et al. 2008). Consequently, assisting the migration of species (also called assisted colonization) has also been proposed as an important climate change adaptation strategy. Several modeling approaches have been developed to predict the migration of species' climate niches (Iverson and Prasad 2002, Hamann and Wang 2006, Rehfeldt et al. 2006, McKenney et al. 2007). As with assisted migration of populations, the climate distance species are moved will have to be small enough to allow for good survival at establishment, but large enough to ensure good adaptation toward the end of the rotation when mean annual increment is (ideally) near its maximum.

While few people object to moving seed sources within a species' current geographic range (assuming seed transfer guidelines are not violated), moving species into new areas is more contentious. McLachlan et al. (2007) point out that the practice is in fact already occurring and encourage politicians, policymakers, and the general public to open up discussion on the topic, focusing on the risks and uncertainty involved in such movements. Hunter (2007) builds on this foundation and suggests that work needs to be done to identify species and sites that are candidates for assisted colonization. A protocol for species movement decisions invites policy-makers to weigh the risks of migrating species outside of their current distributions (Hoegh-Guldberg et al. 2008). Given the precedent in forestry of introducing tree species into new locales, the forestry profession is well placed to engage in this debate.

\section{Conclusions}

Our results show historic and predicted future changes in climate in the context of Ontario and BC seed zones. Changes have been occurring over the last 50 or more years and it appears that even more dramatic changes are likely during this century. These types of spatial data are now available for any jurisdiction in the country. Climate changes are certain to impact forest growth and composition across the country but no doubt in a spatially variable manner. Assisting the migration of seed sources and species has been identified as a key response strategy to address climate change in forestry. All jurisdictions in Canada should re-evaluate their regeneration policies and, more specifically, their seed transfer guidelines to ensure that they account for not only past trends but also future prospects.

\section{Acknowledgements}

This work was supported by Natural Resources Canada, Canadian Forest Service and the British Columbia Ministry of Forests and Range. Special thanks to Kathy Campbell and Kevin Lawrence for figures and data management support.

\section{References}

Aitken, S.N., S. Yeaman, J.A. Holliday, T. Wang and S. CurtisMcLane. 2008. Adaptation, migration or extirpation: climate change outcomes for tree populations. Evolutionary Applications 1: 95-111. Beaulieu, J. and A. Rainville. 2005. Adaptation to climate change: genetic variation is both a short- and a long-term solution. For. Chron. 81: 704-709.

Boer, G.J., G. Flato and D. Ramsden. 2000. A transient climate change simulation with historical and projected greenhouse gas and aerosol forcing: projected climate for the 21st century. Climate Dynamics 16: 427-450.

Bonsal, B.R., X. Zhang, L.A. Vincent and W.D. Hogg. 2001. Characteristics of daily and extreme temperatures over Canada. J. Clim. 14: 1959-1976.

Botkin et al. (18 other authors). 2007. Forecasting the effects of global warming on biodiversity. BioScience 57: 227-235.

Campbell, R.K. 1979. Genecology of Douglas-fir in a watershed in the Oregon Cascades. Ecology 60: 1036-1050.

Carroll, A.L, J. Régnière, J.A. Logan, S.W. Taylor, B.J. Bentz and J.A. Powell. 2007. Impacts of climate change on range expansion by the mountain pine beetle. Natural Resources Canada, Canadian Forest Service, Mountain Pine Beetle Initiative, Project 1.02, Working Paper. 25 p.

Collins, W.D. et al. (14 other authors). 2006. The Community Climate System Model Version 3 (CCSM3). J. Climate 19: 2122-2143.

Crowe, K. A. and W. H. Parker. 2005. Provisional breeding zone determination modeled as a maximal covering location problem. Can. J. For. Res. 35: 1173-1182.

Flannigan, M.D., K.A. Logan, B.D. Amiro, W.R. Skinner and B.J. Stocks. 2005. Future area burned in Canada. Climatic Change. 72: 1-16. Flannigan, M.D. and C.E. Van Wagner. 1991. Climate Change and wildfire in Canada. Can. J. For. Res. 21: 66-72.

Gordon, C., C. Cooper, C.A. Senior, H. Banks, J.M. Gregory, T.C. Johns, J.F.B. Mitchell and R.A. Wood. 2000. The simulation of SST, sea ice extents and ocean heat transports in a version of the Hadley Centre coupled model without flux adjustments. Climate Dynamics 16: $147-168$.

Gordon, H.B. and S.P. O'Farrell. 1997. Transient climate change in the CSIRO coupled model with dynamic sea ice. Monthly Weather Review 125: 875-907.

Grant, R.F. et al. (12 other authors). 2007. Net ecosystem productivity of boreal jack pine stands regenerating from clearcutting under current and future climates. Global Change Biology 13: 1423-1440. Gray, D.R. 2008. The relationship between climate and outbreak characteristics of the spruce budworm in eastern Canada. Climatic Change 87: 361-383.

Gu, L, P.J. Hanson, W.M. Post, D.P. Kaiser, B. Yang, R. Nemani, S.G. Pallardy and T. Meyers. 2008. The 2007 eastern US spring freeze: increased cold damage in a warming world? BioScience 58: 253-262. Hamann, A., M.P. Koshy, G. Namkoong, C.C. Ying. 2000. Genotype $\mathrm{x}$ environment interaction in Alnus rubra: developing seed zones and seed transfer guidelines using spatial statistics and GIS. For. Ecol. Manage. 136: 107-119.

Hamann, A. and T. Wang. 2006. Potential effects of climate change on ecosystem and tree species distribution in British Columbia. Ecology 87: 2773-2786.

Hoegh-Guldberg, O., L. Hughes, S. McIntyre, D.B. Lindenmayer, C. Parmesan, H.P. Possingham and C.D. Thomas. 2008. Assisted colonization and rapid climate change. Science 321: 345-346.

Hogg, E.H. 1997. Temporal scaling of moisture and the forest-grassland boundary in western Canada. Agric. For. Meteorol. 84: 115-122. Hogg, E.H., J.P Brandt and M. Michaelian. 2008. Impacts of a regional drought on the productivity, dieback and biomass of western Canadian aspen forests. Can. J. For. Res. 38: 1373-1384.

Houlder D.J., M.F. Hutchinson, H.A. Nix and J.P. McMahon. 2000. ANUCLIM User Guide, Version 5.1. Centre for Resource and Environmental Studies, Australian National University, Canberra, Australia. 
Hunter, M.L. Jr. 2007. Climate change and moving species: furthering the debate on assisted colonization. Conservation Biology 21: 1356-1358.

Hutchinson, M.F. 2004. ANUSPLIN Version 4.3. Centre for Resource and Environmental Studies, Australian National University, November 23, 2005 [online]. Available at http://cres.anu.edu.au/ outputs/anusplin.php.

IPCC. 2007. Climate change 2007: synthesis report. Contribution of working groups I, II and III to the Fourth Assessment Report of the Intergovernmental Panel on Climate Change. R.K. Pachauri and A. Reisinger (eds.). IPCC, Geneva, Switzerland. 104 p.

Iverson, L.R. and A.M. Prasad. 2002. Potential redistribution of tree species habitat under five climate change scenarios in the eastern US. For. Ecol. Manage. 155: 205-222.

Joyce, D. and R.G. White. 2003. Seed zone definition and seed zone map of Ontario. (20 Nov. 2008) [online]. Available at http://www. mnr.gov.on.ca/en/Business/Forests/2ColumnSubPage/STEL02_166 255.html.

Jump, A.S. and J. Penuelas. 2005. Running to stand still: adaptation and the response of plants to rapid climate change. Ecology Letters 8: 1010-1020.

Körner, C. 2006. Plant $\mathrm{CO}_{2}$ responses: an issue of definition, time and resource supply. New Phytologist 172: 393-411.

Lemprière, T.C., P.Y. Bernier, A.L. Carroll, M.D. Flannigan, R.P. Gilsenan, D.W. McKenney, E.H. Hogg, J.H. Pedlar and D. Blain. 2008. The importance of forest sector adaptation to climate change. Canadian Forest Service, Natural Resources Canada. NOR-X-416E. Lesser, M.R. and W.H. Parker. 2004. Genetic variation in Picea glauca for growth and phenological traits from provenance tests in Ontario. Silvae Genet. 53: 141-148.

Mackey, B.G., D.W. McKenney, Y. Yang, J.P. McMahon and M.F. Hutchinson. 1996. Site regions revisited: a climatic analysis of Hills' site regions for the province of Ontario using a parametric method. Can. J. For. Res. 26: 333-354.

McKenney, D.W., B.G. Mackey and D. Joyce. 1999. Seedwhere: a computer tool to support seed transfer and ecological restoration decisions. Environmental Monitoring and Software 14: 589-595.

McKenney, D.W., J.H. Pedlar, P. Papadopol and M.F. Hutchinson. 2006a. The development of 1901-2000 historical monthly climate models for Canada and the United States. Agricultural and Forest Meteorology 138: 69-81.

McKenney, D.W., J.H. Pedlar, K. Lawrence, K. Campbell and M.F. Hutchinson. 2007. Potential impacts of climate change on the distribution of North American trees. BioScience 57: 939-948.

McKenney, D.W., D. Price, P. Papadapol, M. Siltanen and K. Lawrence. 2006b. High-resolution climate change scenarios for North America. Canadian Forest Service Front Line Technical Note no. 107. Sault Ste. Marie, ON.

McLachlan, J.S. and J.S. Clark. 2004. Reconstructing historical ranges with fossil data at continental scales. For. Ecol. Manage. 197: 139-147.

McLachlan, J.S., J.J. Hellmann and M.W. Schwartz. 2007. A framework for debate of assisted migration in an era of climate change. Conservation Biology 21: 297-302.

Millar, C.I., N.L. Stephenson and S.L. Stephens. 2007. Climate change and forests of the future: managing in the face of uncertainty. Ecological Applications 17: 2145-2151.

Morgenstern, E.K. 1996. Geographic variation in forest trees: genetic basis and application of knowledge in silviculture. University of British Columbia Press, Vancouver, BC. 209 p.

Morgenstern, E.K. and B.S.P. Wang. 2001. Trends in forest depletion, seed supply and reforestation in Canada during the past four decades. For. Chron. 77: 1014-1021.

Nakicenovic, N. and R. Swart. 2000. Special Report on Emissions Scenarios. University Press, Cambridge, UK.

Natural Resources Canada. 2007. The State of Canada's Forests [online]. Natural Resources Canada, Canadian Forest Service, Ottawa, Ontario. Available at www.canadaforests.nrcan.gc.ca.
Norby, R.J. et al. (18 other authors). 2005. Forest response to elevated $\mathrm{CO}_{2}$ is conserved across a broad range of productivity. Proc. Nat. Acad. Sci. 102: 18052-18056.

O'Neill, G.A. and S.A. Aitken. 2004. Area-based breeding zones to minimize maladaptation. Can. J. For. Res. 34: 695-704.

O'Neill, G.A. et al. (10 other authors). 2008. Assisted migration to address climate change in BC: recommendations for interim seed transfer standards. Tech. Rep. 048. British Columbia Ministry of Forests and Range, Research Branch, Victoria, BC.

Parker, W.H. 1992. Focal point seed zones: site specific delineation by geographic information systems. Can. J. For. Res. 22: 267-271.

Parker, W.H. 2000. Rates of change of adaptive variation in Picea mariana visualized by GIS using a differential systematic coefficient. New Forests 20: 259-276.

Parker, W.H., A.M. Thomson and M.R. Lesser. 2006. Identification of jack pine seed sources to compensate for loss of growth resulting from climate change. Final Report - Living Legacy Research Program. Project Number LULL RP-06. 169 p.

Parker, W.H. and A. van Niejenhuis. 1996. Regression-based focal point seed zones for Picea mariana from northwestern Ontario. Can. J. Bot. 74: 1227-1235.

Raymond, C.A. and D. Lindgren. 1990. Genetic flexibility - a model for determining the range of suitable environments for a seed source. Silvae Genet. 39: 112-120.

Raupach, M.R., G. Marland, P. Ciais, C. Le Quéré, J.G. Canadell, G. Klepper and C.B. Field. 2007. Global and regional drivers of accelerating $\mathrm{CO}_{2}$ emissions. Pub. Nat. Acad. Sci. 104: 10288-10293. Rehfeldt, G.E. 1983. Seed transfer in the northern Rocky Mountains. In Proceedings of the USDA Forest Service Forest Genetics Workshop, Charlottetown, South Carolina. pp. 1-26.

Rehfeldt, G.E., N.L. Crookston, M.V. Warwell and J.S. Evans. 2006. Empirical analyses of plant-climate relationships for western United States. Int. J. Plant Sci. 167: 1123-1150.

Rehfeldt, G.E., W.R. Wykoff and C.C. Ying. 2001. Physiologic plasticity, evolution, and impacts of a changing climate on Pinus contorta. Climatic Change 50: 355-376.

Reich P.B. and J. Oleksyn. 2008. Climate warming will reduce growth and survival of Scots pine except in the far north. Ecology Letters 11: 588-597.

SAS Institute Inc. 2003. SAS User's Guide: Statistics. Release 9.1. SAS Inst. Inc., Cary, NC.

Savva, Y., B. Denneler, A. Koubaa, F. Tremblay, Y. Bergeron and M.G. Tjoelker. 2007. Seed transfer and climate change effects on radial growth of jack pine populations in a common garden in Petawawa, Ontario, Canada. For. Ecol. Manage. 242: 636-647.

Stocks, B.J. et al. (10 other authors). 1998. Climate change and forest fire potential in Russian and Canadian boreal forests. Climatic Change 38:1-13.

Vincent, L. and É Mekis. 2006. Changes in daily and extreme temperature and precipitation indices for Canada over the twentieth century. Atmosphere-Ocean 44: 177-193.

Wang, T, A. Hamann, A. Yanchuk, G.A. O'Neill and S.N. Aitken. 2006. Use of response functions in selecting lodgepole pine populations for future climates. Global Change Biology 12: 2404-2416.

Wilf, P. and C.C. Labandeira. 1999. Response of plant-insect associations to Paleocene-Eocene warming. Science 284: 2153-2156.

Wotton, B.M., K.A. Logan and R.S. McAlpine. 2005. Climate change and the future fire environment in Ontario: fire occurrence and fire management impacts. Ontario Ministry of Natural Resources Climate Research Report CCRR-01.32 p.

Ying, C.C. and A.D. Yanchuk. 2006. The development of British Columbia's tree seed transfer guidelines: purpose, concept, methodology, and implementation. For. Ecol. Manage. 227: 1-13.

Zhang, X., W.D. Hogg and É Mekis. 2001. Spatial and temporal characteristics of heavy precipitation events over Canada. J. Clim. 14: 1923-1936. 